\title{
РОЛЬ МЕДИЧНОЇ СЕСТРИ В ОПТИМІЗАЦІЇ ПРОФІЛАКТИЧНИХ ЗАХОДІВ У ХВОРИХ НА ХРОНІЧНЕ ОБСТРУКТИВНЕ ЗАХВОРЮВАННЯ ЛЕГЕНЬ
}

\author{
І. В. Бушинська, Г. І. Набесна, М. М. Жуковська, І. Я. Криницька, \\ М. I. Марущак
}

\author{
ДвНЗ «Тернопільський національний медичний університет \\ імені І. Я. Горбачевського МОЗ Украӥни»
}

\begin{abstract}
У статті проаналізовано вплив розробленого навчального курсу на самопочуття хворих на хронічне обструктивне захворювання легень до і після проведеного навчання. Воно складалося з загальної та спеціальної частини. У загальній частині розглядали питання, які орієнтовані на ведення здорового способу життя (відмову від куріння та алкоголю), організацію умов праці та побуту, первинну та вторинну профілактику захворювань, пропаганду занять фізкультурою та спортом, пропаганду вакцинації проти грипу, показ мультимедійного навчального курсу із ХОЗЛ, вивчення причин загострення хронічного обструктивного захворювання легень та методів їх попередження, обговорення необхідності адекватного та регулярного лікування.
\end{abstract}

\section{THE ROLE OF A NURSE IN OPTIMIZATION OF PREVENTIVE MEASURES FOR PATIENTS WITH CHRONIC OBSTRUCTIVE PULMONARY DISEASE}

\author{
I. V. Bushynska, H. I. Nabesna, M. M. Zhukovska, I. Ya. Krynytska, \\ M. I. Marushchak
}

\section{Horbachevsky Ternopil National Medical University}

\begin{abstract}
The article analyzes the impact of the developed training course on the state of health of patients with chronic obstructive pulmonary disease (COPD) before and after the training. The training includes general and a special parts. General part addresses the issues, oriented on healthy lifestyle (smoking cessation and alcohol), organization of work and living conditions, primary and secondary prevention of diseases, promotion of physical education, sports and influenza vaccination, multimedia COPD training course, understanding the causes of exacerbation of COPD and methods of their prevention, discussion of the need for adequate and regular treatment. The role of a nurse in the prevention of chronic obstructive pulmonary disease is to identify the risk factors of this pathology in particular patient and conduct special individual training. It improves both physical and emotional state of patients with COPD.
\end{abstract}

Вступ. Хронічне обструктивне захворювання легень (ХОЗЛ) є загальною прогресуючою хронічною хворобою, що характеризується стійким обмеженням повітряного потоку та такими респіраторними скаргами, як задишка, хронічний кашель і харкотиння, які, головним чином, зумовлені незворотною обструкцією дихальних шляхів [1]. Крім респіраторних скарг, пацієнти з ХОЗЛ стикаються з іншими обмеженнями у повсякденному житті, викликаними дисфункцією м'язів і супутніми захворюваннями [2]. Перебіг ХОЗЛ непередбачуваний і характеризується періодами, в яких стан пацієнта погіршується. Першим і найголовнішим фактором ризику розвитку ХОЗЛ $\epsilon$ тютюнокуріння.
Крім того, такі зовнішні фактори ризику, як пасивне куріння, забруднення навколишнього повітря, а також професійний вплив пилу та шкідливих частинок збільшують ризик виникнення ХОЗЛ [3]. Підраховано, що близько 328 млн людей (160 млн жінок і 168 млн чоловіків) мають ХОЗЛ у всьому світі [4]. За прогнозами ВООЗ, ХОЗЛ стане четвертою причиною смерті до 2035 р. Разом з іншими хронічними захворюваннями (діабет, деменція і рак) на ХОЗЛ припадає значна частина в структурі захворюваності, продовжуючи бути основною проблемою у системі охорони здоров'я [5].

Змінюється не лише фізична, але й емоційна та соціальна якість життя хворих на ХОЗЛ [6]. Клінічний

(ㄱ І. В. Бушинська, Г. І. Набесна, М. М. Жуковська, І. Я. Криницька, М. І. Марущак, 2019

8 ISSN 2411-1597. МЕДСЕСТРИНСТВО. 2019. № 2 
діагноз ХОЗЛ ґрунтується на ступені обмеження повітряного потоку (тобто зменшення об'єму форсованого видиху за одну секунду (ОФВ1)), при цьому індивідуальні відмінності у щоденному функціонуванні та якості життя таких хворих не враховуються [7]. Доведено, що ОФВ1 не корелює з показниками якості життя хворих на ХОЗЛ [8]. Розроблений ряд біопсихосоціальних моделей припускає, що, крім біологічних аспектів, психологічні та соціальні фактори відіграють важливу роль у пристосуванні до хронічної хвороби [9]. Щоб зрозуміти складність життя з ХОЗЛ, важливо з'ясувати, які фактори, крім фізичних скарг, пов'язані з повсякденною діяльністю і якістю життя.

Мета роботи: проаналізувати вплив розробленого навчального курсу на самопочуття хворих на ХОЗЛ до і після проведеного навчання.

Основна частина. Лікарі загальної практики і медичні сестри відіграють важливу роль у профілактиці й інтегрованому догляді за хворими на ХОЗЛ [2]. Зокрема роль медсестер стає все більш важливою, оскільки сестринська допомога характеризується безперервністю догляду. Медичні сестри беруть участь на всіх етапах захворювання, починаючи від профілактики ХОЗЛ аж до догляду за станом життя таких хворих [10]. Медсестри значно розширили свою практику в останні роки, проте ефективність сестринського догляду за результатами охорони здоров'я залишається низькою [11-13]. Більше того, у більшості випадків медсестри не мають достатніх знань і навичок для запобігання негативним наслідкам і покращення якості життя хворих на ХОЗЛ. Дослідження ролі медсестер у догляді за хворими з ХОЗЛ варто розширювати.

У дослідженні взяли участь 28 хворих, з них 15 чоловіків і 13 жінок, середній вік - $(56 \pm 1,35)$ року. Основним критерієм включення у дослідження $є$ наявність стабільної ХОЗЛ. 3 дослідження виключали хворих на ХОЗЛ вкрай тяжкого перебігу з явищами тяжкої дихальної недостатності, які за своїм станом не здатні засвоювати навчальний матеріал, пацієнтів із гострими супутніми захворюваннями, хворих з порушенням ментальних здібностей і соціального статусу, що передбачає нездатність пацієнтів виконувати рекомендації.

Навчання складалося з загальної та спеціальної частини. У загальній частині розглядали питання, які орієнтовані на ведення здорового способу життя (відмову від куріння та алкоголю), організацію умов праці та побуту, первинну та вторинну профілактику захворювань, пропаганду занять фізкультурою та спортом, пропаганду вакцинації проти грипу, показ мультимедійного навчального курсу із хОЗЛ, вивчення причин загострення ХОЗЛ та методів їх попередження, обговорення необхідності адекватного та регулярного лікування.

Було проаналізовано основні фактори, що спричинили ХОЗЛ, у пацієнтів, включених у дослідження шляхом використання оригінальної анкети для ранньої діагностики ХОЗЛ, складеної відповідно до наказу МО3 України від 27.06.2013 р. № 555. Спеціальне навчання включало індивідуальні заняття з пацієнтами, спрямовані на модифікацію основних факторів ризику хОЗЛ, консультації із харчування хворих, консультації із фізичної реабілітації (дихальна гімнастика, дозована хода), методику проведення пікфлоуриметрії.

Основними факторами ризику, поширеність яких ми вивчали за даними анкетування, були куріння, частота респіраторних інфекцій, схильність до алергій, обтяжений сімейний анамнез. Встановлено, щоу пацієнтів, включених у дослідження, обтяжений спадковий (17 осіб) й алергологічний анамнез (19 осіб). При цьому, найбільше респондентів мали стаж куріння 11-20 років і лише 3 хворих на момент встановлення діагнозу ХОЗЛ не курили. Варто також відзначити, що переважна кількість хворих на ХОЗЛ має часті респіраторні інфекційні захворювання (рис. 1). Тому в частину спеціального навчання було включено спеціальний цикл щодо відмови від куріння, а також шляхи профілактики алергій та вірусних інфекцій.

Для оцінки самопочуття пацієнтів із ХОЗЛ ми поставили їм по 2 запитання на предмет їх фізичного та емоційного стану: 1. Як Ви оцінюєте свій емоційний стан, настрій на сьогодні? 2. Як Ви оцінюєте свій стан здоров'я, фізичний стан на сьогодні?

Свій емоційний стан пацієнти оцінили по-різному, проте жоден із досліджуваних не почував себе на відмінно. Так, пацієнти оцінили свій емоційний стан як добрий у 10,9 \% випадків, задовільний - в 25,0 \% випадків, незадовільний -у 9,4\% випадків. Відповідно, пацієнти оцінили свій фізичний стан як добрий у 7,8 \% випадків, задовільний - в 26,6 \% випадків, незадовільний - у 9,4 \% випадків (табл. 1). Аналізуючи отримані дані, можна стверджувати, що пацієнти пов'язують свій емоційний стан із фізичним здоров'ям.

Самооцінка емоційного та фізичного стану пацієнтів, які пройшли навчальний курс, значно підвищилася. Свій емоційний стан хворі оцінили по-різному, проте жоден із досліджуваних не почував себе незадовільно, 2 пацієнтів оцінили свій емоційний стан як 

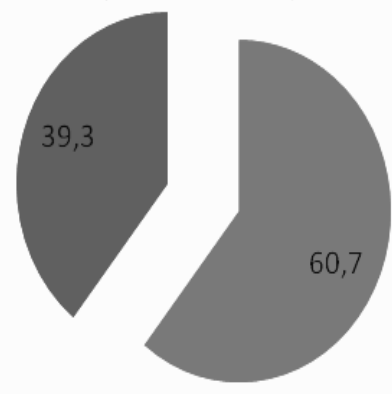

птак

口і

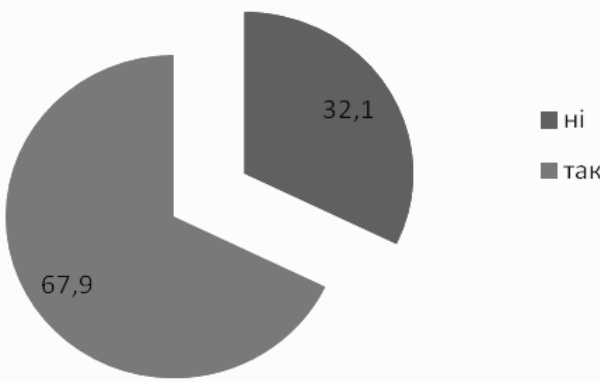

Стаж куріння (\%)

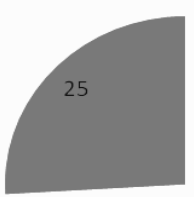

10,7

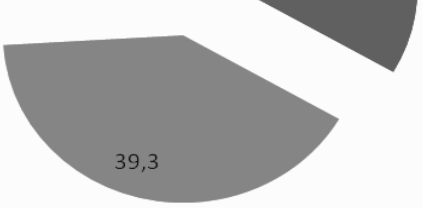

- 5-10 років

—11-20 років

понад 20 років

Як часто Ви хворієте на респіраторні вірусні інфекції протягом року? (\%)

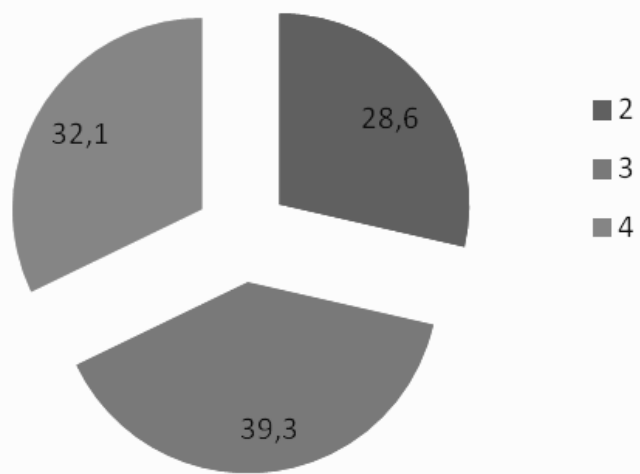

Рис. 1. Розподіл основних факторів ризику серед хворих на хронічне обструктивне захворювання легень.

\section{Таблиця 1. Самооцінка емоційного та фізичного стану пацієнтів із ХОзл}

\begin{tabular}{|l|c|c|c|c|c|}
\hline \multicolumn{1}{|c|}{ Самооцінка } & Відмінна & Добра & Задовільна & $\begin{array}{c}\text { Незадо- } \\
\text { вільна }\end{array}$ & $\begin{array}{c}\text { Складно } \\
\text { відповісти }\end{array}$ \\
\hline Емоційний стан, настрій на сьогодні & - & 6 & 15 & 5 & 2 \\
\hline Стан здоров'я, свій фізичний стан на сьогодні & - & 1 & 16 & 5 & 3 \\
\hline
\end{tabular}

відмінний. Відповідно, пацієнти оцінили свій фізичний стан як добрий у $26,6 \%$ випадків.

Дослідження хворих на ХОЗЛ, опубліковане в журналі Chest, зазначає, що 16,2 \% пацієнтів із тяжким ХОЗЛ також мають депресивні або тривожні розлади [14]. В іншому дослідженні, опублікованому в журналі Thorax, виявлено, що наявність ХОЗЛ підвищує ризик розвитку в пацієнта депресії або тривоги у 85 \% [15]. Інше дослідження засвідчує, що психологічний і емо-

\section{СПИСОК ЛІТЕРАТУРИ}

1. Fletcher M. J. Expanding nurse practice in COPD: Is it key to providing high quality, effective and safe patient care? / M. J. Fletcher, B. H. Dahl // Prim. Care Respir. J. - 2013. Vol. 22 (2). - P. 230-233.

2. Long Alliantie Nederland (LAN). Zorgstandaard COPD. 2012. ційний стан пацієнта залежить від фізичного стану хворого на ХОЗЛ [16].

Висновки. Роль медичної сестри у профілактиці хронічного обструктивного захворювання легень полягає у виявленні факторів ризику цієї патології у конкретного хворого і проведенні спеціального індивідуального навчання. Це покращує не тільки фізичне, а й емоційне самопочуття хворих на ХОЗЛ.

3. Truglio J. Global health and primary care: Increasing burden of chronic diseases and need for integrated training / J. Truglio, M. Graziano, R. Vedanthan // Mt. Sinai J. Med. 2012. - Vol. 79 (4). P. 464-474.

4. GOLD. Global strategy for the diagnosis, management and prevention of COPD, global initiative for chronic 
obstructive lung disease (GOLD) - 2015. - URL : www. goldcopd.com

5. Craig P. Developing and evaluating complex interventions: Reflections on the 2008 MRC guidance / P. Craig, M. Petticrew // Int. J. Nurs. Stud. - 2013. - Vol. 50 (5). - P. 585-587.

6. Moore G. F. Process evaluation of complex interventions: Medical research council guidance / G. F. Moore, S. Audrey, M. Barker // BMJ. - 2015. - Vol. 350. - P. h1258.

7. Lewin S. Use of qualitative methods alongside randomised controlled trials of complex healthcare interventions: Methodological study / S. Lewin, C. Glenton, A. D. Oxman // BMJ. - 2009. - Vol. 339. - P. b3496.

8. Fischer M. J. Concerns about exercise are related to walk test results in pulmonary rehabilitation for patients with COPD / M. J. Fischer, M. Scharloo, J. Abbink // Int. J. Behav. Med. - 2012. - Vol. (19). - P. 39-47.

9. Perceived quality of life in chronic obstructive pulmonary disease patients: A cross-sectional study in primary care on the role of illness perceptions / S. W. Weldam, J. W. Lammers, M. J. Heijmans, M. J. Schuurmans // BMC Fam Pract. - 2014. Vol. 15. - P. 140.

10. Why the nation needs a policy push on patientcentered health care / R. M. Epstein, K. Fiscella, C. S. Lesser, K. C. Stange // Health Affairs. 2010. - Vol. 29 (8). - P. 14891495.
11. Jonsdottir H. Effectiveness of a partnership-based self-management programme for patients with mild and moderate chronic obstructive pulmonary disease: A pragmatic randomized controlled trial / $\mathrm{H}$. Jonsdottir, O. R. Amundadottir, G. Gudmundsson //J. Adv. Nurs. - 2015. doi: 10.1111/jan.12728.

12. Clinical trial of community nurse mentoring to improve self-management in patients with chronic obstructive pulmonary disease / R. Wood-Baker, D. Reid, A. Robinson, E. H. Walters // Int. J. Chron .Obstruct. Pulmon. Dis. - 2012. Vol. 7. - P. 407-413.

13. Jonsdottir H. Self-management programmes for people living with chronic obstructive pulmonary disease: A call for a reconceptualisation / H. Jonsdottir // J. Clin. Nurs. - 2013. Vol. 22 (5-6). - P. 621-637.

14. Schneider C. COPD and the risk of depression / C. Schneider // CHEST. - 2010. - Vol. 137, Iss. 2. - P. 341-347.

15. Influence of anxiety on health outcomes in COPD / M. D. Eisner, P. D. Blanc, E. H. Yelin [et al.] // Thorax. - 2010. Vol. 65 (3). - P. 229-234.

16. Support needs of patients with COPD: a systematic literature search and narrative review / A. C. Gardener, G. Ewing, I. Kuhn, M. Farquhar // International Journal of Chronic Obstructive Pulmonary Disease. - 2018. - Vol. 13.P. 1021-1035.

Отримано 05.03.19 